\title{
Acupuncture therapeutic protocols for the management of temporomandibular disorders *
}

\author{
Protocolos de acupuntura para o tratamento da disfunção temporomandibular
}

André Luís Porporatti' ${ }^{1}$ Yuri Martins Costa ${ }^{1}$, Juliana Stuginski-Barbosa ${ }^{1}$, Leonardo Rigoldi Bonjardim², Paulo César Rodrigues Conti ${ }^{1}$

${ }^{*}$ Received from the Prosthesis Department, School of Dentistry of Bauru, University of São Paulo, Bauru, SP, Brazil.

DOI 10.5935/1806-0013.20150011

\section{ABSTRACT}

BACKGROUND AND OBJECTIVES: For most cases, temporomandibular disorders should be treated by a non-invasive, interdisciplinary and integrative process. In traditional Chinese medicine, acupuncture is an excellent tool aiming at treating and healing this disease. This study was a critical literature review to observe the efficacy of traditional Chinese acupuncture to treat muscular temporomandibular disorders and to identify primary acupoints.

CONTENTS: Pubmed, LILACS, Scielo and Cochrane databases were queried to identify scientific articles relevant for the study. Articles were selected from January 2000 to May 2013. A total of 125 articles were found and 21 were included. Acupuncture treatment alone or as additional therapy, or even compared to other techniques, was superior and effective to improve pain and function of patients with temporomandibular disorders and most commonly used acupoints were IG4, E6, E7 and F3.

CONCLUSION: This study has shown that acupuncture is a technique recommended by national and international literature to treat muscular temporomandibular disorders, promoting pain relief and/or total intensity, improvement of joint movements and oral function and decrease of masticatory muscles hyperactivity.

Keywords: Acupuncture analgesia, Acupuncture points, Facial pain, Temporomandibular disorder syndrome, Temporomandibular joint disorder.

1. University of São Paulo, School of Dentistry of Bauru, Prosthesis Department, Bauru, SP, Brazil.

2. University of São Paulo, School of Dentistry of Bauru, Department of Biological Sciences, Bauru, SP, Brazil.

Submitted in October 04, 2014.

Accepted for publication in December 11, 2014.

Conflict of interests: none - Sponsoring sources: none.

Correspondence to:

André Luís Porporatti

Al. Octávio Pinheiro Brizolla, 9-75 - Vila Universitária

17012-901Bauru, SP, Brasil.

E-mail:andreporporatti@yahoo.com.br

(C) Sociedade Brasileira para o Estudo da Dor

\section{RESUMO}

JUSTIFICATIVA E OBJETIVOS: Na grande maioria dos casos, o tratamento das disfunçóes temporomandibulares deve ser um processo não invasivo, interdisciplinar e integrativo. Dentro da medicina tradicional chinesa, a acupuntura é uma ótima ferramenta que visa a terapia e cura dessas doenças. O objetivo deste estudo foi conduzir uma revisão crítica da literatura para verificar a eficácia da acupuntura tradicional chinesa no tratamento da disfunção temporomandibular do tipo muscular, bem como identificar os principais acupontos.

CONTEÚDO: Foi realizada uma pesquisa nas bases de dados Pubmed, LILACS, Scielo e Cochrane para identificar artigos científicos relevantes para o estudo. Os artigos foram selecionados no período de janeiro de 2000 a maio de 2013 . Encontrou-se um total de 125 artigos, sendo que 21 foram incluídos. $\mathrm{O}$ tratamento de acupuntura isolado ou como terapia complementar, ou ainda comparado com outras técnicas, se mostrou superior e eficiente na melhora da dor e da função de pacientes com disfunção temporomandibular, e os pontos de acupuntura mais citados foram IG4, E6, E7 e F3.

CONCLUSÁO: Este estudo demonstrou que a acupuntura é uma técnica recomendada pela literatura nacional e internacional para o tratamento de disfunçôes temporomandibulares de origem muscular, promovendo alivio e/ou redução total da intensidade dolorosa, melhora nos movimentos mandibulares e na função oral e diminuição da hiperatividade muscular dos músculos da mastigação.

Descritores: Analgesia por acupuntura, Dor facial, Pontos de acupuntura, Síndrome da disfunção da articulação temporomandibular, Transtornos da articulação temporomandibular.

\section{INTRODUCTION}

Orofacial pain is associated to head, face and neck soft tissues and may be defined as dysfunction and pain affecting sensory and motor transmission in the trigeminal nervous system ${ }^{1}$. Among pains affecting this region there are temporomandibular disorders (TMD) which represent a collective term related to a group of musculoskeletal and joint problems which affect the temporomandibular joint (TMJ) and associated structures $^{1,2}$. TMD may present as facial pain, stiffness sensation, joint sounds (clicks), deviation of mandibular midline, restricted movements and pain during function ${ }^{3}$. Among such 
disorders, one should stress myofascial pain, which has been documented as the most prevalent disorder in this region ${ }^{1,2}$ and may affect individuals' routine to a greater or lesser extent ${ }^{4-6}$. Current interventions to manage TMDs involve therapies with muscle relaxant plates, drugs, physiotherapy, self-care guidance and education and surgeries ${ }^{7,8}$. Noninvasive or even nonsurgical therapies are the most widely used and prescribed therapies and according to the literature they have been very successful to date?

Studies have shown that $74 \%$ of patients with TMD look for conservative, more alternative and complementary therapies, especially looking for manual therapies, massage therapy and acupuncture ${ }^{10,11}$. Acupuncture is indicated and effective to manage TMD, based on pain decrease mechanisms, anti-inflammatory properties and with endocrine neuro-hormonal effects ${ }^{9,11}$.

The Traditional Chinese Medicine (TCM) is an energetic medicine, that is, it is based on the existence of an energetic structure beyond the physical body, and states that in our body the energy circulates by channels or meridians which, when punctured, reorganize the energetic circulation throughout the body. Disease, in turn, is always a disorganization of the functional energy which controls and dynamizes organs. Chinese philosophical conception about the universe is based on three basic pillars: Yang/Yin theory, five movements and Zang Fu (organs and viscerae) ${ }^{12,13}$.

Acupuncture aims at managing and healing diseases by the application of skin stimuli with the insertion of needles on specific points called acupoints ${ }^{14,15}$. This is also a reflex therapy where the stimulation of one area acts on other(s). For such, it primarily uses nociceptive stimuli ${ }^{14,15}$.

This study aimed at carrying out a critical literature review, in Portuguese and English, to check the efficacy of traditional Chinese acupuncture to treat muscle-type TMD, as well as at identifying major acupoints which will help guiding clinical approaches of acupuncture professionals.

\section{CONTENTS}

PubMed, LILACS, Scielo and Cochrane (including Central Cochrane) databases were searched to identify scientific articles relevant to the study. Articles were selected from January 2000 to May 2013 using the following keywords (DeCS Descriptors in Health Science): Temporomandibular Disorder AND Acupuncture OR Chinese Acupuncture OR Acupuncture Techniques, in Portuguese and English languages.

After the search, a previous screening of articles was carried out, based on articles title and abstract, excluding possible publications unrelated to the subject. Then, criteria for the final selection of articles were applied. Table 1 shows the results of the search.

\section{Studies selection criteria}

Controlled randomized studies, cohort clinical trials, clinical studies, case-control studies, cross-sectional studies and case series reports having in their methodology the application of
Table 1. Result of the search carried out in different literature databases.

\begin{tabular}{lccc}
\hline Databases & Results & $\begin{array}{c}\text { Initial } \\
\text { selection } \\
\text { by title }\end{array}$ & $\begin{array}{c}\text { After applying } \\
\text { inclusion and } \\
\text { exclusion criteria }\end{array}$ \\
\hline PubMed & 116 & 67 & 20 \\
LILACS & 07 & 03 & 02 \\
Scielo & 01 & 01 & 00 \\
Cochrane (including & 01 & 00 & 00 \\
Central Cochrane) & 125 & 71 & 21 \\
Subtotal & 01 & 01 & 01 \\
Repeated articles & 124 & 70 & 21 \\
Total & & & \\
\hline
\end{tabular}

different acupuncture techniques, types of used points and meridians, were included. Case reports, systematic literature reviews and literature reviews were excluded.

Inclusion criteria were limited to studies where participants were:

- Humans of both genders, aged between 18 and 80 years;

- Individuals diagnosed with muscle-type TMD, meeting the following criteria:

\section{Criteria for muscle $\mathrm{TMD}^{1,6}$}

Myofascial pain in masseter and/or temporal masticatory muscles:

- Pain on mandible, temple or ear region in the last month;

- Pain modified with movement, function or parafunction;

- Report of family pain at masseter or temporal muscle palpation;

- Individuals with our without mouth opening limitation;

- Individual with muscle pain caused by systemic diseases, patients with toothache, individuals with psychological disorders previously identified and individuals with recent history of face and neck trauma were excluded.

Relevant data were part of studies where acupuncture protocols were applied to patients with muscle-type TMD and whose results were mentioned in the study.

\section{Data collection}

A reviewer has selected articles as from abstract data and in cases when abstracts were unavailable, through title information. Relevant data for this stage were type of study and sample profiles. Selected articles should also meet all selection criteria in their complete publication.

\section{Articles review}

The next step was to evaluate selected articles to determine their internal and external validity. If there was inadequate information not allowing criteria evaluation, the author would be contacted by e-mail to explain study design and characteristics.

We have found 125 potential scientific articles. After analyzing the abstract, 21 articles were selected to be fully evaluated. One hundred and four articles were excluded from the study for not meeting inclusion criteria. Among them, 25 articles were dated before 2000 , five were excluded for being a single 
clinical case report, two articles had no relevant results and just clinical observations and five articles were not written in the defined standard language (two in Spanish, one in German and two in Chinese). A total of 54 articles were excluded for not matching the theme proposed by this review.
The 21 selected articles are shown in table 2. Most articles are in English being just two in Portuguese.

Tables 2 and 3 show major features of included studies, such as studied disease, primary treatment (treatment recommended and treatment of choice for the case), additional treat-

Table 2. Summarized information of articles about treatment, number of sessions and number of evaluated patients

\begin{tabular}{|c|c|c|c|c|c|}
\hline Authors & $\begin{array}{l}\text { Studied } \\
\text { disease }\end{array}$ & Primary treatment & Additional treatment & $\begin{array}{l}\text { Number of pa- } \\
\text { tients }\end{array}$ & $\begin{array}{l}\text { Acupuncture } \\
\text { sessions }\end{array}$ \\
\hline $\begin{array}{l}\text { Ferreira, de Oliveira, } \\
\text { Guimaraes, et al. }{ }^{16}\end{array}$ & Chronic TMD & Muscle relaxant plates & $\begin{array}{l}\text { To compare real laserthe- } \\
\text { rapy to placebo laser in } \\
\text { acupuncture points }\end{array}$ & $\begin{array}{l}14 \text { (7 for each } \\
\text { group) }\end{array}$ & 12 \\
\hline $\begin{array}{l}\text { Ritenbaugh, } \\
\text { Hammerschlag } \\
\text { Dworkin, et al. }{ }^{17}\end{array}$ & Chronic TMD & Muscle relaxant plates & $\begin{array}{l}\text { Compare Traditional } \\
\text { Chinese Medicine (acu- } \\
\text { puncture, phytotherapy, } \\
\text { massage) to guidance }\end{array}$ & $\begin{array}{l}168 \text { ( } 84 \text { for each } \\
\text { group) }\end{array}$ & 20 \\
\hline $\begin{array}{l}\text { Vicente-Barrero, Yu- } \\
\text { Lu, Zhang, et al. }{ }^{18}\end{array}$ & TMD & $\begin{array}{l}\text { Compare acupuncture with Muscle rela- } \\
\text { xant plates }\end{array}$ & None & $\begin{array}{l}20 \text { (10 for each } \\
\text { group) }\end{array}$ & 15 \\
\hline $\begin{array}{l}\text { Itoh, Asai, Ohyabu, } \\
\text { et al. }{ }^{19}\end{array}$ & Chronic TMD & $\begin{array}{l}\text { Compare real trigger points needling to } \\
\text { placebo (sham) }\end{array}$ & None & $\begin{array}{l}16 \text { (8 for each } \\
\text { group) }\end{array}$ & 5 \\
\hline $\begin{array}{l}\text { Borin, Corrêa, Silva, } \\
\text { et al. }{ }^{20}\end{array}$ & TMD & $\begin{array}{l}\text { Compare acupuncture with control (no } \\
\text { treatment) }\end{array}$ & None & $\begin{array}{l}40 \text { (20 for each } \\
\text { group) }\end{array}$ & 10 \\
\hline $\begin{array}{l}\text { Borin, Corrêa, Silva, } \\
\text { et al. }{ }^{21}\end{array}$ & TMD & $\begin{array}{l}\text { Compare acupuncture with control (no } \\
\text { treatment) }\end{array}$ & None & $\begin{array}{l}40 \text { (20 for each } \\
\text { group) }\end{array}$ & 10 \\
\hline $\begin{array}{l}\text { Bu, Chen, Chen, et } \\
\text { al. }^{22}\end{array}$ & Acute TMD & $\begin{array}{l}\text { Compare electroacupuncture to electro- } \\
\text { acupuncture + massage therapy }\end{array}$ & None & $\begin{array}{l}96 \text { (48 for each } \\
\text { group) }\end{array}$ & 1 \\
\hline $\begin{array}{l}\text { Noiman, Garty, } \\
\text { Maimon, et al. }{ }^{23}\end{array}$ & $\begin{array}{l}\text { TMD and } \\
\text { trigeminal } \\
\text { neuralgia }\end{array}$ & $\begin{array}{l}\text { Acupuncture (local and distant techni- } \\
\text { que) }\end{array}$ & None & $\begin{array}{l}35 \text { with TMD and } 4 \\
\text { with neuralgia }\end{array}$ & 08 to 10 \\
\hline $\begin{array}{l}\text { Hotta, Hotta, } \\
\text { Bataglion, et al. }{ }^{24}\end{array}$ & TMD & Lasertherapy in acupuncture points & None & 10 & 10 \\
\hline $\begin{array}{l}\text { Simma, Gleditsch, } \\
\text { Simma, et al. }{ }^{25}\end{array}$ & TMD & $\begin{array}{l}\text { Compare acupuncture with control } \\
\text { (sham) }\end{array}$ & None & $\begin{array}{c}23 \text { (11 real and } 12 \\
\text { placebo) }\end{array}$ & 1 \\
\hline $\begin{array}{l}\text { Rancan, Bataglion, } \\
\text { Bataglion, et al. }{ }^{26}\end{array}$ & TMD & Traditional acupuncture & None & 17 & 10 \\
\hline $\begin{array}{l}\text { Shen, Younger, } \\
\text { Goddard, et al. }{ }^{27}\end{array}$ & TMD & $\begin{array}{l}\text { Compare acupuncture with placebo } \\
\text { acupuncture (sham) }\end{array}$ & None & $\begin{array}{c}28 \text { (16 real and } 12 \\
\text { placebo) }\end{array}$ & 1 \\
\hline Wang eZhang ${ }^{28}$ & TMD & $\begin{array}{l}\text { Compare acupuncture + electromagne- } \\
\text { tictherapy to electromagnetictherapy }\end{array}$ & None & $\begin{array}{l}82 \text { (52 acupunctu- } \\
\text { re + magnetic and } \\
30 \text { magnetic only) }\end{array}$ & 1 \\
\hline Shen e Goddard ${ }^{29}$ & TMD & $\begin{array}{l}\text { Compare acupuncture with placebo } \\
\text { acupuncture (sham) }\end{array}$ & None & $\begin{array}{l}15 \text { (09 real and } 06 \\
\text { placebo) }\end{array}$ & 1 \\
\hline $\begin{array}{l}\text { Smith, Mosscrop, } \\
\text { Davies, et al. }{ }^{30}\end{array}$ & TMD & $\begin{array}{l}\text { Compare acupuncture with placebo } \\
\text { acupuncture (sham) }\end{array}$ & None & 27 & 6 \\
\hline $\begin{array}{l}\text { Shin, Ha, Song, et } \\
\text { al. }^{31}\end{array}$ & TMD & $\begin{array}{l}\text { Treatment with acupuncture and massa- } \\
\text { ge therapy }\end{array}$ & None & 49 & 08 to10 \\
\hline $\begin{array}{l}\text { Schmid-Schwap, } \\
\text { Simma-Kletschka, } \\
\text { Stockner, et al. }{ }^{32}\end{array}$ & TMD & $\begin{array}{l}\text { Compare acupuncture with placebo acu- } \\
\text { puncture (Laser in randomized points) }\end{array}$ & None & 23 & 1 \\
\hline Goddard $^{33}$ & TMD & Traditional acupuncture & None & 29 & 1 \\
\hline Wong e Cheng ${ }^{34}$ & TMD & $\begin{array}{l}\text { Traditional acupuncture }+ \text { muscle rela- } \\
\text { xant plate }+ \text { trigger points injection }\end{array}$ & None & 85 & 6 \\
\hline $\begin{array}{l}\text { DeBar, Vuckovic, } \\
\text { Schneider, et al. }{ }^{10}\end{array}$ & TMD & $\begin{array}{l}\text { Application of questionnaires about Tra- } \\
\text { ditional Chinese Medicine }\end{array}$ & None & 192 & Not specified \\
\hline $\begin{array}{l}\text { Goddard, Karibe, } \\
\text { McNeill, et al. }{ }^{35}\end{array}$ & TMD & $\begin{array}{l}\text { Compare acupuncture in recognized } \\
\text { acupoints to placebo acupuncture in } \\
\text { non recognized points or away from me- } \\
\text { ridians location }\end{array}$ & None & $\begin{array}{l}18 \text { (10 real acu- } \\
\text { puncture, } 8 \text { place- } \\
\text { bo acupuncture) }\end{array}$ & 1 \\
\hline
\end{tabular}


Table 3. Summarized information of articles about acupuncture points used and results obtained

\begin{tabular}{|c|c|c|}
\hline Authors & Acupoints & Results \\
\hline $\begin{array}{l}\text { Ferreira, de Oliveira, } \\
\text { Guimaraes,et al. }{ }^{.6}\end{array}$ & $\begin{array}{l}\text { E6, ID19, VB20, VB43, IG4, F3, TA3 } \\
\text { and Yintang }\end{array}$ & $\begin{array}{l}\text { Real laser has shown significantly faster improvement with greater pain de- } \\
\text { crease }\end{array}$ \\
\hline $\begin{array}{l}\text { Ritenbaugh, } \\
\text { Hammerschlag, } \\
\text { Dworkin, et al. }{ }^{17}\end{array}$ & $\begin{array}{l}\text { E7 and/or E6, VB20 and/or VB21, } \\
\text { F3, F4 and Taiyang }\end{array}$ & $\begin{array}{l}\text { Faster pain and quality of life improvement of patients receiving Chinese East- } \\
\text { ern treatment as compared to those who just received guidance }\end{array}$ \\
\hline $\begin{array}{l}\text { Vicente-Barrero, } \\
\text { Yu-Lu, Zhang, et al. }{ }^{18}\end{array}$ & $\begin{array}{l}\text { Local points: TA21, VB21, TA17, } \\
\text { E6 and Taiyang. Distant points: F4, } \\
\text { E36, TA5 and VB34 }\end{array}$ & $\begin{array}{l}\text { Results for both groups were similar, showing pain decrease and less pain at } \\
\text { pressure in temporal and masseter muscles }\end{array}$ \\
\hline $\begin{array}{l}\text { Itoh, Asai, Ohyabu, } \\
\text { et al. }{ }^{19}\end{array}$ & $\begin{array}{l}\text { Ashi points (painful points at pres- } \\
\text { sure or trigger points) }\end{array}$ & $\begin{array}{l}\text { Much higher pain intensity decrease in the group receiving real needling on tri- } \\
\text { gger points, however there has been no difference between groups with regard } \\
\text { to movement and oral function improvement }\end{array}$ \\
\hline $\begin{array}{l}\text { Borin, Corrêa, Silva, } \\
\text { et al. }{ }^{20}\end{array}$ & $\begin{array}{l}\text { E7, E5, TA17, VB43, IG4, Taiyang } \\
\text { and Yintang }\end{array}$ & $\begin{array}{l}\text { Acupuncture has decreased temporal muscles activity in the position of man- } \\
\text { dibular rest, providing better muscle balance between these and masseter } \\
\text { muscles }\end{array}$ \\
\hline $\begin{array}{l}\text { Borin, Corrêa, Silva, } \\
\text { et al. }{ }^{21}\end{array}$ & $\begin{array}{l}\text { E7, E5, TA17, VB43, IG4, Taiyang } \\
\text { and Yintang }\end{array}$ & $\begin{array}{l}\text { There has been significant decrease in pain and severity of temporomandibular } \\
\text { disorder after treatment with acupuncture. Control group had no improvement }\end{array}$ \\
\hline $\begin{array}{l}\text { Bu, Chen, Chen, et } \\
\text { al. }{ }^{22}\end{array}$ & VB3, E7, E6, ID19 and IG4 & $\begin{array}{l}\text { Effective improvement for the group with acupuncture }+ \text { massage therapy as } \\
\text { compared to acupuncture alone }\end{array}$ \\
\hline $\begin{array}{l}\text { Noiman, Garty A, } \\
\text { Maimon Y, et al. }{ }^{23}\end{array}$ & $\begin{array}{l}\text { Local: Ashi or trigger points, Dis- } \\
\text { tant: varied in the region of hand or } \\
\text { foot. In general IG4 and F3 }\end{array}$ & $\begin{array}{l}\text { Patients with temporomandibular disorder had } 88.6 \% \text { pain improvement, whi- } \\
\text { le just } 25 \% \text { of patients with neuralgia had improvement }\end{array}$ \\
\hline $\begin{array}{l}\text { Hotta, Hotta, } \\
\text { Bataglion, et al. }{ }^{24}\end{array}$ & IG4, C3, E6 and E7 & Significant improvement in painful symptoms and masseter muscle function \\
\hline $\begin{array}{l}\text { Simma, Gleditsch, } \\
\text { Simma, et al. } .^{25}\end{array}$ & Ashi points or trigger points & $\begin{array}{l}\text { Pain decrease was significantly better after acupuncture as compared to pla- } \\
\text { cebo treatment }\end{array}$ \\
\hline $\begin{array}{l}\text { Rancan, Bataglion, } \\
\text { Bataglion, et al. }{ }^{26}\end{array}$ & $\begin{array}{l}\text { IG4, E6, E7, B2, VB14, VB20, ID18, } \\
\text { ID19, F3, E36, VB34, E44 and R3 }\end{array}$ & $\begin{array}{l}\text { Decreased muscle activity during jaw movements and teeth clenching and } \\
\text { decreased pain after acupuncture }\end{array}$ \\
\hline $\begin{array}{l}\text { Shen, Younger, } \\
\text { Goddard, et al. } .^{27}\end{array}$ & IG4 & $\begin{array}{l}\text { Decreased pain and sensitivity of masticatory/face and neck muscles only for } \\
\text { the group receiving real acupuncture }\end{array}$ \\
\hline Wang \& Zhang ${ }^{28}$ & E7, E6, IG4 & $\begin{array}{l}\text { Significant pain improvement in } 90.4 \% \text { of the acupuncture + magnetic group, } \\
\text { while improvement for the control group was only } 66.7 \% \text {. }\end{array}$ \\
\hline Shen \& Goddard 29 & IG4 & $\begin{array}{l}\text { Significant improvement of facial pain, neck pain and headache for real acu- } \\
\text { puncture }\end{array}$ \\
\hline $\begin{array}{l}\text { Smith, Mosscrop, } \\
\text { Davies, et al. }{ }^{30}\end{array}$ & E7 & Better influence of real acupuncture on clinical results as compared to placebo \\
\hline Shin, $\mathrm{Ha}$, Song, et al. ${ }^{31}$ & ID18, ID19, E6, E7, TA17 and IG4 & Proposed treatment has significantly improved pain and mouth opening \\
\hline $\begin{array}{l}\text { Schmid-Schwap, } \\
\text { Simma-Kletschka, } \\
\text { Stockner, et al. }{ }^{32}\end{array}$ & $\begin{array}{l}\text { Maxilla and mandible retromolar } \\
\text { region, mandible and maxilla ves- } \\
\text { tibular region. Extraoral points: } \\
\text { IG4, ID2 and ID3 }\end{array}$ & $\begin{array}{l}\text { Decreased pain, better mouth opening and improved muscle sensitivity to pal- } \\
\text { pation for the group receiving real acupuncture }\end{array}$ \\
\hline Goddard $^{33}$ & $\begin{array}{l}\text { Varied on a patient-by-patient ba- } \\
\text { sis, however IG4 was always used }\end{array}$ & Significant pain intensity decrease from 5.28 to 2.26 \\
\hline Wong \& Cheng 34 & $\begin{array}{l}\text { Local: E7, E6, ID17 and extra point } \\
\text { QianZheng, distant: IG4, TA5, F3 } \\
\text { and E36 }\end{array}$ & $85 \%$ of patients with temporomandibular disorder had relieved symtoms \\
\hline $\begin{array}{l}\text { DeBar, Vuckovic, } \\
\text { Schneider, et al. }{ }^{10}\end{array}$ & Not specified & $\begin{array}{l}63 \% \text { of patients reported using Traditional Chinese Medicine to treat temporo- } \\
\text { mandibular disorder pain, being acupuncture, massage therapy and chyropra- } \\
\text { xis the most satisfactory and helpful for patients }\end{array}$ \\
\hline $\begin{array}{l}\text { Goddard, Karibe, } \\
\text { McNeill, et al. }{ }^{35}\end{array}$ & $\begin{array}{l}\text { IG4 and E6 (real acupuncture) and } \\
\text { points close to IG4 and E6 for pla- } \\
\text { cebo }\end{array}$ & $\begin{array}{l}\text { Both groups had significant pain intensity decrease, without difference betwe- } \\
\text { en groups }\end{array}$ \\
\hline
\end{tabular}


ment, number of evaluated and treated patients, number of acupuncture sessions, as well as the list of all major acupuncture points used and results found with a certain technique or comparison among techniques.
Most described and applied meridians were stomach, with 26 cases, followed by large intestine with 15 cases and gall bladder with 12 cases. Figures 1 and 2 describe all points mentioned by the 21 included articles.

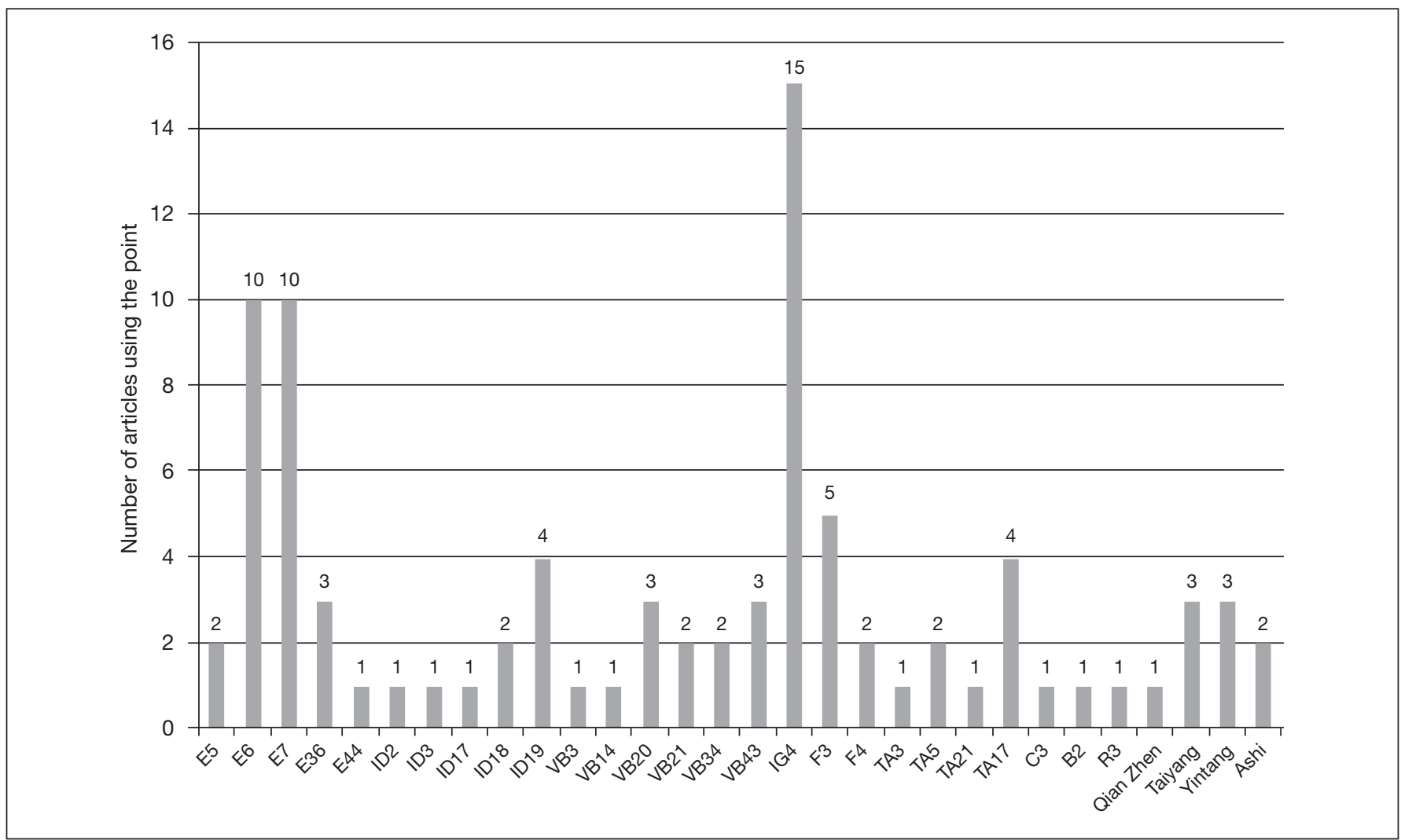

Figure 1. Most common acupuncture meridians used in the articles

$\mathrm{E}$ = stomach; ID = small intestine; $\mathrm{VB}=$ gallbladder; $\mathrm{IG}$ = large intestine; $\mathrm{F}=$ liver; $\mathrm{TA}=$ triple heater; $\mathrm{C}=$ heart; $\mathrm{B}=$ bladder; $\mathrm{R}=$ kidney.

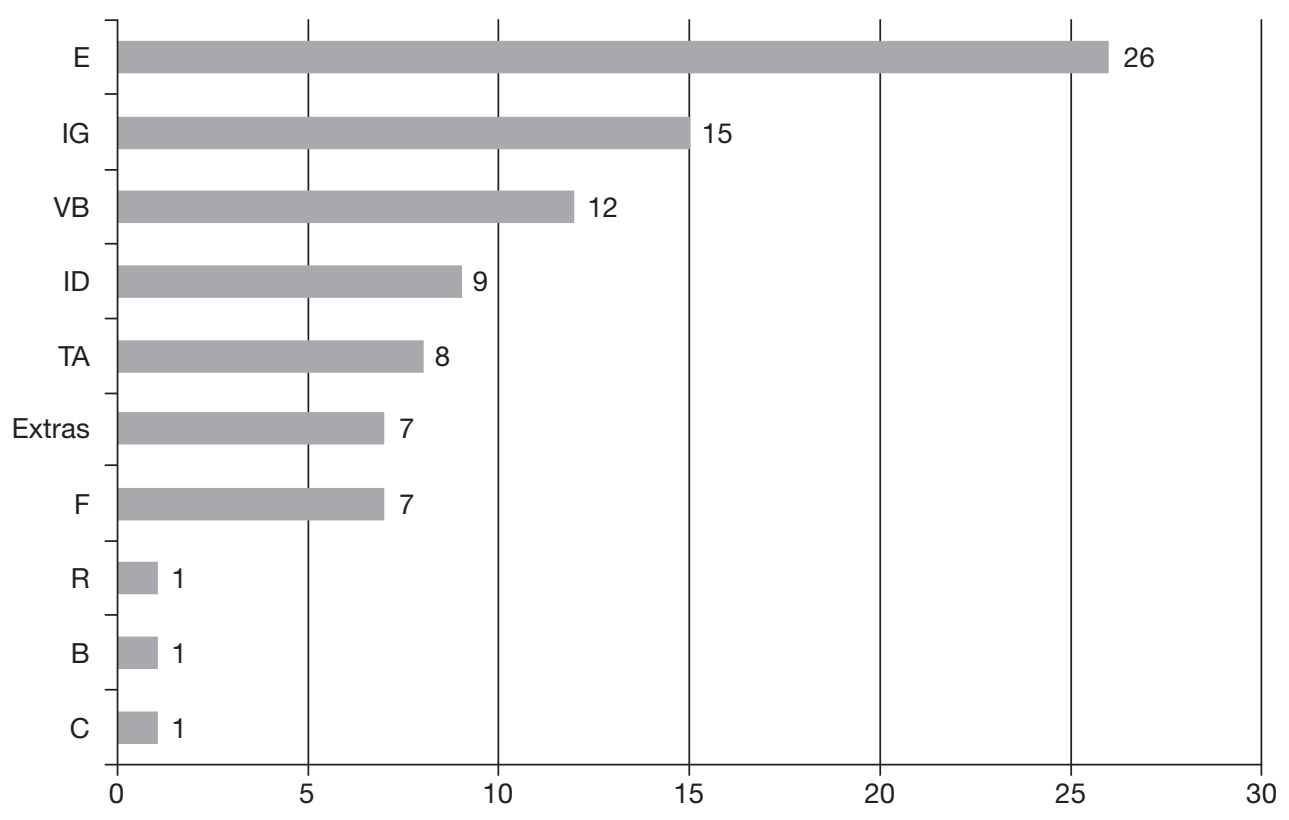

Figure 2. Acupuncture meridians used in more articles

$\mathrm{E}=$ stomach; $\mathrm{ID}=$ small intestine; $\mathrm{VB}=$ gallbladder; $\mathrm{IG}=$ large intestine; $\mathrm{F}=$ liver; $\mathrm{TA}=$ triple heater; $\mathrm{C}=$ heart; $\mathrm{B}=$ bladder; $\mathrm{R}=$ kidney. 


\section{DISCUSSION}

This study has provided data showing that acupuncture is a TCM technique indicated and recommended by national and international literature to treat TMD. In most of the 21 articles selected and described in this review, acupuncture alone or as complementary therapy or even as compared to other techniques was superior and efficient to improve pain and function of patients with muscle-type TMD.

Acupuncture directly impacts mental stress, decreases anxiety and improves sleep quality. Acupuncture holistic approach allows dealing with other comorbidities, as well as with integrative problems, such as headache and body pain, aiming at reaching physical and mental balance ${ }^{27}$.

Studies have shown that acupuncture to treat musculoskeletal pain is a promising technique. In a study with 92 patients, $69 \%$ had good or excellent response to treatment, with at least $30 \%$ pain decrease ${ }^{36}$.

In our study, all articles show a predilection for IG4 as a distant point with very strong energetic action. IG4 has excellent function as potent anti-inflammatory and analgesic ${ }^{13,36}$. Even so, many meridians and points had more indications and utilization. In 17\% of all cases, IG4 was used as the point of choice to treat muscle TMD, followed by $11 \%$ of points E6 and E7 and 6\% of point $\mathrm{F} 3$. Also, in $4 \%$ of cases, points ID 19 and TA17 were indicated.

It is also interesting to note that some extra points were more frequently used, indicating that their prescription should be always recommended. Points Taiyang and Yintang are extra points of easy access and greatly improve painful symptoms of TMD patients ${ }^{27}$.

Currently, and following the Western vision, channels or meridians through which the whole energy of our body circulates are considered integrative or functional areas where there is the participation of several local and systemic systems, such as nervous, circulatory, lymphatic, endocrine and immune systems, among others ${ }^{17,26,36}$.

Acupuncture action mechanisms may be explained by three principles. The first is based on the placebo effect of the technique, which is somehow controversial, because acupuncture is effectively used also in non-suggestible beings such as animals and plants ${ }^{37}$. The second principle is based on Mendell's control gate theory ${ }^{38}$ and the third principle involves the descending release by the central nervous system of hormones and neurochemical substances such as steroids, endorphin, serotonin and other natural analgesics ${ }^{39}$.

The biggest problem of current scientific studies using acupuncture as treatment is primarily based on the Western theory of creating therapeutic protocols for each case. For example, to treat patients with muscle TMD, one should use specific acupuncture points. However, acupuncture is a TCM technique which presents an energetic diagnosis and tailors the treatment for each patient, inter-relating consequences for the environment, emotional, psychosocial and biological factors.

Scientific articles, in addition to creating therapeutic proto- cols, have always a Western diagnosis and the treatment is the same, with the same acupoints for the whole sample. So, when analyzing articles using acupuncture as therapy, one should observe that acupuncture is an Eastern technique looking for tailoring patients' treatment and always in search of a more holistic vision. Obviously, each scientific article has to standardize its methodology, and treatment tailoring is very often unfeasible.

\section{CONCLUSION}

Muscle TMD treatment with acupuncture promotes pain relief and/or total intensity decrease, improves jaw movements and decreases muscle hyperactivity of masticatory muscles. Acupuncture professionals should have in mind that some points were effective to treat muscle TMD, such as stomach, large intestine and gall bladder acupoints.

TMD patients may, in most cases, resort to acupuncture as alternative, complementary or even primary treatment to decrease painful symptoms and to improve oral function.

\section{REFERENCES}

1. De Leeuw R. Orofacial Pain: Guidelines for Assessment, Diagnosis, and Management. American Academy of Orofacial Pain. $4^{\text {th }}$ ed. Chicago: Quintessence; 2008.

2. Okeson JP. Bell`s orofacial pains. $6^{\text {th }}$ ed. Chicago: Quintessence; 2005.

3. Rocha AP. Dor: aspectos atuais da sensibilizaçâo periférica e central. Rev Bras Anestesiol. 2007;57(1):94-105.

4. Mcneill C. Temporomandibular disorders: guidelines for classification, assessment and management. $2^{\text {nd }}$ ed. Chicago: Quintessence; 1993.

5. Manfredini D, Guarda-Nardini L, Winocur E, Piccotti F, Ahlberg J, Lobbezoo F. Research diagnostic criteria for temporomandibular disorders: a systematic review of axis I epidemiologic findings. Oral Surg Oral Med Oral Pathol Oral Radiol Endod. 2011;112(4):453-62.

6. Dworkin SF, LeResche L. Research diagnostic criteria for temporomandibular disorders: review, criteria, examinations and specifications, critique. J Craniomandib Disord. 1992;6(4):301-55.

7. Conti PC, de Alencar EN, da Mota Correa AS, Lauris JR, Porporatti AL, Costa YM. Behavioural changes and occlusal splints are effective in the management of masticatory myofascial pain: a short-term evaluation. J Oral Rehabil. 2012;39(10):754-60.

8. Conti PC, Ferreira PM, Pegoraro LF, Conti JV, Salvador MC. A cross-sectional study of prevalence and etiology of signs and symptoms of temporomandibular disorders in high school and university students. J Orofac Pain. 1996;10(3):254-62.

9. Jung A, Shin BC, Lee MS, Sim H, Ernst E. Acupuncture for treating temporomandibular joint disorders: a systematic review and meta-analysis of randomized, sham-controlled trials. J Dent. 2011;39(5):341-50.

10. DeBar LL, Vuckovic N, Schneider J, Ritenbaugh C. Use of complementary and alternative medicine for temporomandibular disorders. J Orofac Pain. 2003;17(3):224-36.

11. Lin JG, Chen WL. Acupuncture analgesia: a review of its mechanisms of actions. Am J Chin Med. 2008;36(4):635-45.

12. Autoroche B, Navailh P. O Diagnóstico na Medicina Chinesa. São Paulo, Brasil: Andrei Editora; 1986.

13. Maciocia G. Os Fundamentos da Medicina Chinesa. São Paulo: Rocca; 1996

14. Jaggar D. History and basic introduction to veterinary acupuncture. Probl Vet Med.1992;4(1):1-11

15. Lundeberg T. Peripheral effects of sensory nerve stimulation (acupuncture) in inflammation and ischemia. Scand J Rehabil Med Suppl. 1993;29:61-86.

16. Ferreira LA, de Oliveira RG, Guimarães JP, Carvalho AC, De Paula MV. Laser acupuncture in patients with temporomandibular dysfunction: a randomized controlled trial. Lasers Med Sci. 2013;28(6):1549-58.

17. Ritenbaugh C, Hammerschlag R, Dworkin SF, Aickin MG, Mist SD, Elder CR, et al. Comparative effectiveness of traditional chinese medicine and psychosocial care in the treatment of temporomandibular disorders-associated chronic facial pain. J Pain. 2012;13(11):1075-89.

18. Vicente-Barrero M, Yu-Lu SL, Zhang B, Bocanegra-Perez S, Duran-Moreno D, Lopez-Marquez A, et al. The efficacy of acupuncture and decompression splints in the treatment of temporomandibular joint pain-dysfunction syndrome. Med Oral Patol Oral Cir Bucal. 2012;17(6):e1028-33.

19. Itoh K, Asai S, Ohyabu H, Imai K, Kitakoji H. Effects of trigger point acupuncture 
treatment on temporomandibular disorders: a preliminary randomized clinical trial. J Acupunct Meridian Stud. 2012;5(2):57-62.

20. Borin GS, Corrêa EC, Silva AM, Milanes JM. Avaliaçẫo eletromiográfica dos músculos da mastigaçáo de indivíduos com desordem temporomandibular submetidos a acupuntura. Rev Soc Bras Fonoaudiol. 2012;17(1):1-8.

21. Borin GS, Corrêa EC, Silva AM, Milanes JM. Acupuntura como recurso terapêutico na dor e na gravidade da desordem temporomandibular. Fisioter Pesq. 2011;18(3):218-22.

22. Bu LX, Chen T, Chen X, Jing H, Li NY. [Clinical observation of acupuncture and massage therapy for temporomandibular joint disorders]. Shanghai Kou Qiang Yi Xue. 2011;20(3):292-5.Chinese.

23. Noiman M, Garty A, Maimon Y, Miller U, Lev-Ari S. Acupuncture for treating temporomandibular disorder: retrospective study on safety and efficacy. J Acupunct Meridian Stud. 2010;3(4):260-6.

24. Hotta PT, Hotta TH, Bataglion C, Bataglion SA, de Souza Coronatto EA, Siéssere $S$, et al. Emg analysis after laser acupuncture in patients with temporomandibular dysfunction (TMD). Implications for practice. Complement Ther Clin Pract. 2010;16(3):158-60

25. Simma I, Gleditsch JM, Simma L, Piehslinger E. Immediate effects of micro system acupuncture in patients with oromyofacial pain and craniomandibular disorders (CMD): a double-blind, placebo-controlled trial. Br Dent J. 2009;19;207(12):E26.

26. Rancan SV, Bataglion C, Bataglion SA, Bechara OM, Semprini M, Siéssere S, et al. Acupuncture and temporomandibular disorders: a 3-month follow-up EMG study. J Alter Complement Med. 2009;15(12):1307-10.

27. Shen YF, Younger J, Goddard G, Mackey S. Randomized clinical trial of acupuncture for miofascial pain of the jaw muscles. J Orofac Pain. 2009;23(4):353-9.

28. Wang XH, Zhang W. [Acupuncture combined with magnetic therapy for treatment of temple-jaw joint dysfunction]. Zhongguo Zhen Jiu. 2009;29(4):279-80.Chinese.
29. Shen YF, Goddard G. The short-term effects of acupuncture on miofascial pain patients after clenching. Pain Pract. 2007;7(3):256-64.

30. Smith P, Mosscrop D, Davies S, Sloan P, Al-Ani Z. The efficacy of acupuncture in the treatment of temporomandibular joint miofascial pain: a randomized controlled trial. J Dent. 2007;35(3):259-67.

31. Shin BC, $\mathrm{Ha} \mathrm{CH}$, Song YS, Lee MS. Effectiveness of combining manual therapy and acupuncture on temporomandibular joint dysfunction: a retrospective study. Am J Chin Med. 2007;35(2):203-8.

32. Schmid-Schwap M, Simma-Kletschka I, Stockner A, Sengstbratl M, Gleditsch J, Kundi M, et al. Oral acupuncture in the therapy of craniomandibular dysfunction syndrome - a randomized controlled trial. Wien Klin Wochenschr. 2006;118(1-2):36-42.

33. Goddard G. Short term pain reduction with acupuncture treatment for chronic orofacial pain patients. Med Sci Monit. 2005;11(2):CR71-4.

34. Wong YK, Cheng J. A case series of temporomandibular disorders treated with acupuncture, oclusal splint and point injection therapy. Acupunct Med. 2003;21(4):138-49.

35. Goddard G, Karibe H, McNeill C, Villafuerte E. Acupuncture and sham acupuncture reduce muscle pain in miofascial pain patients. J Orofac Pain. 2002;16(1):71-6.

36. Kam E, Eslick G, Campbell I. An audit of the effectiveness of acupuncture on musculoskeletal pain in primary health care. Acupunct Med. 2002;20(1):35-8.

37. Kirsch I, Kong J, Sadler P, Spaeth R, Cook A, Kaptchuk T, et al. Expectancy and conditioning in placebo analgesia: separate or connected processes? Psychol Conscious. 2014;1(1):51-9.

38. Mendell LM. Constructing and deconstructing the gate theory of pain. Pain. 2014;155(2):210-6.

39. Zhan DW, Sun JH, Luo KT, Xu LZ, Zhou JL, Pei LX, et al. [Effects and efficacy observation of acupuncture on serum 5-HT in patients with diarrhea-predominant irritable bowels syndrome]. Zhonffuo Zhen Jiu. 2014;34(2):135-8.Chinese. 